Вісник ЛДУБЖД

Bulletin of Lviv State University of Life Safety
ISSN 2078-4643 (print), ISSN 2708-1389 (online)

https://journal.ldubgd.edu.ua/index.php/Visnuk/

UDC 808.51

DOI: 10.32447/20784643.23.2021.07

Ewa Zieliński', Maciej Zieliński ${ }^{1}$, Bernard Motylewski ${ }^{1}$, Dariusz Skalski, Karolina Brzoskowska ${ }^{2}\left({ }^{1}\right.$ Nicolaus Copernicus University, Toruń, Poland; ${ }^{2}$ Academy of Physical

Education and Sport for them. of Jędrzej Śniadecki in Gdańsk)

\title{
STUDY OF ADOLESCENTS' AWARENESS OF THE EFFECTS OF SMOKING IN ORDER TO INCREASE THE EFFECTIVENESS OF CANCER PREVENTION
}

In Poland and the world, cancer is a serious health problem. There are the second cause of death in total and the first cause of death before the age of 65 in Poland. The paper presents some research results concerning the understanding of the level of knowledge of adolescents about lung cancer. An attempt was made to answer the question: Do young people have basic knowledge about lung cancer? The following hypotheses were made: Students believe that they influence whether they will develop lung cancer. Adolescents have a basic knowledge of lung cancer. The obtained results allowed for the formulation of conclusions. The main goal of the work is to find out about the level of knowledge of young people about lung cancer.

To improve the situation of lung cancer in society, numerous social organizations and associations take part in social campaigns dedicated to all citizens, regardless of age and sex. Some postulates, the introduction of which could increase the health security of the state and eliminate some environmental threats, such as passive smoking, will be presented below. These postulates have the overarching goal of changing the model of lung cancer prevention and care in Poland. The changes should be comprehensive - from prevention (primary and secondary), through diagnostics and treatment, post-treatment care (including rehabilitation and psycho-oncological care), to observation aimed at detecting and treating complications of the disease and anti-cancer therapy as well as early detection of possible recurrence of the disease. Given that smoking is becoming a bad habit of the younger age group than the study, it would be worthwhile to expand the age range and conduct such research among children, for example, from the age of 7 years. At this age, children are more receptive to and aware of health hazards.

Keywords: lung cancer, health hazard, cancer prevention, smoking.

Ева Зелінська ${ }^{1}$, Мацей Зелінський ${ }^{1}$ Бернард Мотилевський ${ }^{1}$, Даріуш Скальський², Кароліна Бюжосковська ${ }^{2}\left({ }^{1}\right.$ Університет Миколи Коперника, Торунь, Польща; ${ }^{2}$ Академія фізичного виховання та спорту імені Снджея Снядецького в Гданську)

\section{ВИВЧЕННЯ ОБІЗНАНОСТІ ПІДЛІТКІВ ПРО ВПЛИВ КУРІННЯ 3 МЕТОЮ ПІДВИЩЕННЯ ЕФЕКТИВНОСТІ ПРОФІЛАКТИКИ РАКУ}

У Польщі та у світі рак є серйозною проблемою для здоров'я. Дана хвороба є другою причиною смерті в Польщі та першою причиною смерті до 65 років. У статті представлені деякі результати досліджень щодо розуміння обізнаності підлітків про рак легенів. Була зроблена спроба відповісти на запитання: Чи має молодь базові знання про рак легенів? Були висловлені такі гіпотези: Студенти вважають, що вони впливають на те, чи не буде у них рак легенів. Підлітки мають базові знання про рак легенів. Отримані результати дозволили сформулювати висновки. Основна мета роботи - з'ясувати рівень обізнаності молоді про рак легенів.

3 метою покращення ситуації з раком легенів у суспільстві численні соціальні організації та об'єднання беруть участь у соціальних кампаніях, присвячених усім громадянам, незалежно від віку та статі. Деякі постулати, впровадження яких могло б підвищити безпеку здоров'я держави та усунути деякі екологічні загрози, такі як пасивне куріння, будуть представлені нижче. Ці постулати мають головну мету змінити модель профілактики та догляду за раком легенів у Польщі. Етіологія деяких видів раку незрозуміла. Вони є результатом багатьох 
генетичних мутацій, на які можуть впливати різні фізичні та хімічні фактори, вірусні інфекції, тип дієти, стимулятори. Розвиток раку - це повільний процес (кілька років) або агресивно швидкий (один місяць). Зміни повинні бути комплексними - від профілактики (первинної та вторинної), через діагностику та лікування, долікування (включаючи реабілітацію та психо-онкологічну допомогу), до спостереження, спрямованого на виявлення та лікування ускладнень захворювання та протиракової терапії, а також раннє виявлення можливого рецидиву захворювання. Враховуючи, що куріння стає шкідливою звичкою молодшої вікової групи, варто було б розширити віковий діапазон і проводити такі дослідження серед дітей, наприклад, починаючи з 7 років. У цьому віці діти більш сприйнятливі та усвідомлюють небезпеку для здоров’я.

Ключові слова - рак легенів, небезпека для здоров'я, профілактика раку, куріння.

Introduction. The relatively higher number of deaths due to lung cancer with the number of cases indicates a deficiency in lung cancer incidence registration. In recent years, the incidence and mortality of lung cancer have been decreasing in men and increasing in women. Approximately $13.5 \%$ of lung cancer patients in Poland survive five years after diagnosis. The risk of developing lung cancer depends on many factors, such as exposure to the carcinogenic components of tobacco smoke (active and passive smoking). It is estimated that tobacco smoke contains about 4,800 chemical compounds. The link between lung cancer and cigarette smoking was proven over fifty years ago by Sir Richard Doll. The most effective way to reduce disease and death from lung cancer is to eradicate smoking from the human population. Smokers often underestimate the dangers of cigarette addiction. Despite many warnings and anti-smoking campaigns, many people find it difficult to break out of the trap of addiction. Lung cancer is a rare disease in the non-smoking population (6/105), while its incidence among smokers is over 20 times higher [2]. The risk of developing lung cancer is fewer dependents on certain physical and chemical environmental hazards (e.g. radon, nickel, chromium, arsenic, asbestos, hydrocarbons). Genetic factors play a significant role here [3]. An important aspect of the fight against lung cancer is effective health prevention by the state. It is about the so-called state health security. Ensuring the safety, including health, of the population in the face of environmental threats requires an institutionalized organization. [4]. Each country determines a set of internal values that should be protected against threats and adopts a set of measures appropriate to the type of threats to protect these values [5].

Health is considered the highest value for humans [6]. Mateusz Paplicki is inclined to say that health security is the certainty of the operation of government and local administration bodies and their subordinate services in the field of life and health protection. Moreover, health security is a process of continuous efforts of the state and the individual to satisfy their health needs. However, due to the limited financial possibilities of the state, health security is a subjective right consisting in satisfying by the state only those health needs that result from a sudden threat to health or life [7]. Certainly, these needs include the prevention and treatment of lung cancer, because in a way its occurrence depends on environmental threats. It should be emphasized that the hitherto attempts at pharmacological prophylaxis of lung cancer and reduction of mortality as a result of screening with the use of X-rays (X-ray) and cytological examination of sputum have proved ineffective. Chest computed tomography (CT) scans are of more value as a screening test. The results of the National Lung Screening Trial (NLST) showed a 20\% reduction in lung cancer mortality in high-risk subjects (55-74 years of age and 30 years of smoking with one pack of cigarettes a day - history of CT scan) thoracic in comparison with the control group (X-ray examination) [8]. Lung cancer early detection programs should involve highly specialized centres with the ability to diagnose and treat this cancer as well as appropriate experience. An important role in the process of lung cancer prevention should be played by a preventive program and social campaigns targeted at people of all ages. Perhaps the imaging of factors predisposing to the occurrence of lung cancer could have the intended effect, which is to make the public aware that certain health behaviours harm health and threaten human life. The same factors deteriorate the quality of human life and can often be the cause of pain and suffering for the patient and their families.

Objective. The main goal of the work is to find out about the level of knowledge of young people about lung cancer.

Methods. The study was conducted in March 2019. in a group of 60 youth ( 30 women and 30 men) aged 14-16randomly selected from schools in the Kuyavian-Pomeranian Voivodeship.

The research tool was the author's survey containing closed questions. Participation in the study was voluntary and anonymous. The survey was addressed to able-bodied persons and an attempt was made to answer the following issues. The respondents were asked about demographic data, prophylaxis, risk factors and symptoms of lung cancer. The survey was conducted during lessons called "Day for Health" in schools. Questionnaires of the survey were distributed in 5 places in the school and students were informed by educators about the possibility of taking part in the study. Filled out surveys, students threw in sealed boxes. After the study completed, the research 
team took the survey boxes and analyzed the responses. Researchers are aware of the small number of students studied. During the conduct of the research, they encountered obstacles expressed by the negative attitude of school principals to conduct such research in their institutions. Headteachers saw no need to obtain such information from students and therefore, the research did not continue.

Results. The results were developed using Microsoft Excel 2010 from the Windows 7 package, using the appropriately available spreadsheet functions.

Table 1 below presents the surveyed students by age and sex.

Table 1. Research students by age and sex (source: own research)

\begin{tabular}{||c|c|c|c|c|c|c||}
\hline \multirow{3}{*}{ Age } & \multicolumn{4}{|c|}{ Respondents } & \multicolumn{2}{c|}{ Altogether } \\
\cline { 2 - 7 } & \multicolumn{2}{|c|}{ Women } & \multicolumn{2}{c|}{ Men } & \multicolumn{2}{c|}{} \\
\cline { 2 - 7 } & $\begin{array}{c}\text { Num- } \\
\text { ber }\end{array}$ & $\%$ & $\begin{array}{c}\text { Num- } \\
\text { ber }\end{array}$ & $\%$ & $\begin{array}{c}\text { Num- } \\
\text { ber }\end{array}$ & $\%$ \\
\hline 15years & 5 & 20 & 15 & 50 & 20 & 34 \\
\hline 16years & 20 & 60 & 6 & 20 & 26 & 45 \\
\hline 17years & 5 & 20 & 9 & 30 & 14 & 21 \\
\hline Sum & $\mathbf{3 0}$ & $\mathbf{1 0 0}$ & $\mathbf{3 0}$ & $\mathbf{1 0 0}$ & $\mathbf{6 0}$ & $\mathbf{1 0 0}$ \\
\hline
\end{tabular}

Of the 60 correctly completed questionnaires qualified for the analysis, $30(50 \%)$ were completed by women and $30(50 \%)$ by men. At age 15, there were $5(20 \%)$ women and $15(50 \%)$ men. At age 16, there were $20(60 \%)$ women and $6(20 \%)$ men. Whereas at the age of 17 there were $5(20 \%)$ women and $9(30 \%)$ men. As you can see, the largest group of respondents were women and men aged 16 years.

Table 2 below presents the surveyed students by place of residence.

Table 2. Research students by place of residence (source: own research)

\begin{tabular}{|c|c|c|c|c|c|}
\hline \multicolumn{4}{|c|}{ Place of residence } & \multirow{2}{*}{\multicolumn{2}{|c|}{ In all }} \\
\hline & & & & & \\
\hline $\begin{array}{c}\text { Num- } \\
\text { ber }\end{array}$ & $\%$ & $\begin{array}{c}\text { Num- } \\
\text { ber }\end{array}$ & $\%$ & $\begin{array}{c}\text { Num- } \\
\text { ber }\end{array}$ & $\%$ \\
\hline 50 & 83 & 10 & 17 & 60 & 100 \\
\hline
\end{tabular}

Most respondents lived in the city - 50 people, which constituted $83 \%$ of the sample, and 10 people lived in the countryside, i.e. $17 \%$ of the respondents.

The students' views on cancer are presented in Table 3 below.

Table 3. Students' opinion on neoplastic diseases (source: own research)

\begin{tabular}{||c|c|c|}
\hline \multirow{2}{*}{ Possible answers } & \multicolumn{2}{|c|}{ Subjects } \\
\cline { 2 - 3 } & Number & $\%$ \\
\hline $\begin{array}{l}\text { I have an influence on } \\
\text { whether I get cancer }\end{array}$ & 32 & 53 \\
\hline
\end{tabular}

\begin{tabular}{|l|c|c|}
\hline $\begin{array}{l}\text { I have no influence on get- } \\
\text { ting cancer }\end{array}$ & 12 & 20 \\
\hline $\begin{array}{l}\text { I don't think about cancer } \\
\text { at all }\end{array}$ & 16 & 27 \\
\hline sum & $\mathbf{6 0}$ & $\mathbf{1 0 0}$ \\
\hline
\end{tabular}

Figure 1 below graphically illustrates students' opinions about cancer.

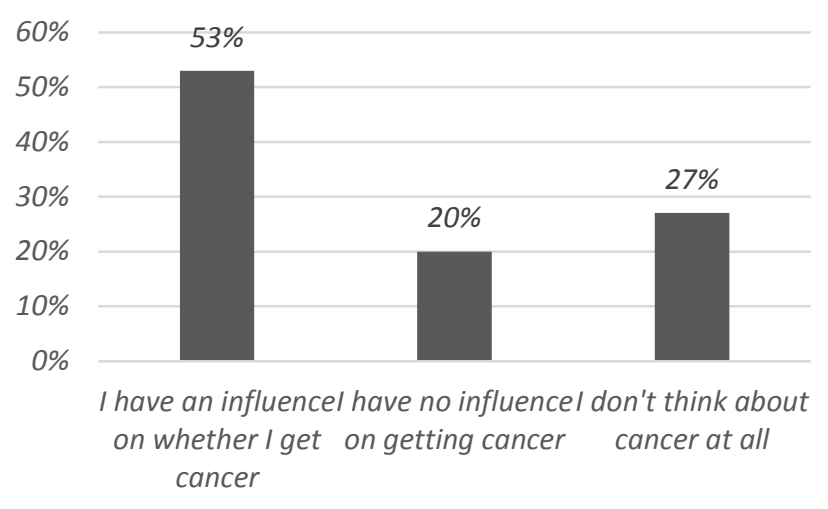

Figure 1 - Students' opinion on neoplastic diseases (source: own research)

To the first question, I influence whether I get cancer", 32 people replied in the affirmative, which is $53 \%$. To the second question, I do not influence getting cancer", 12people replied in the affirmative, which is $20 \%$. To the third question, I don't think about cancer at all", 16 people answered yes, which is $27 \%$ of the respondents

Prevention, risk factors and symptoms of lung cancer in the opinion of the surveyed students.

The survey was conducted among girls and boys aged 15-17 years, the level of knowledge of people about lung cancer was examined. The results of the surveys are summarized in Tables 4-7 and are shown in Figures 2-5.

According to $33(55 \%)$ respondents, smoking is harmful to health. Cigarettes contain nicotine, which is a highly addictive substance. As many as 28 $(47 \%)$ of the respondents indicated the harmful effects of tobacco smoke on human health. The above group of respondents knows that the substances contained in cigarette smoke are carcinogenic. 27 (45\%) of the respondents chose both responses, as shown in Figure 2.

$41(68 \%)$ of the respondents believe that smoking is a risk factor for lung cancer, and 39 (65\%) also indicate passive smoking (inhaling tobacco smoke), $17(28 \%)$ lung cancer prevalence in the family, while $19(32 \%)$ all of the above-mentioned answers, as shown in Table 5.

The respondents also answered the question about lung cancer prophylaxis methods. Only 3 (5\%) of the respondents could not choose the correct answer. Most people, as many as 51 out of 60 , which 
constitute $(85 \%)$, indicated giving up smoking, tobacco products and e-cigarettes as a method of lung cancer prevention.

Slightly less than half of the 17 respondents (28\%) indicated prophylactic tests for early lung cancer detection as prophylaxis. Taking into account the young age of the respondents, this result is satisfactory. $8(13 \%)$ of the respondents indicated increased physical activity as a prophylactic method against lung cancer. Successively respondents marked the following answers from the questionnaire: regular consumption of fruit 7 (12\%); the consumption of anti-cancer vegetables and the knowledge of the potential symptoms of lung cancer were equally marked $6(10 \%)$. The obtained data are presented in Figure 4 below. On the other hand, the most common symptoms of lung cancer are presented in Table 7.

These are mainly hemoptysis of 47 people $(78 \%)$, groats $30(50 \%)$ and dyspnoea $23(38 \%)$; According to $6(10 \%)$ respondents, wheezing is the most common symptom of lung cancer. $9(15 \%)$ in turn, the respondents indicated: as symptoms: hoarseness 5 (8\%); chest pain $4(6 \%)$ and fatigue $4(6 \%)$. Also, 4 respondents $(6 \%)$ did not know about the symptoms of the disease.

Table 4 below shows the level of knowledge about the harmfulness of cigarette smoking.

Table 4. The level of the respondents' knowledge about the harmfulness of smoking (source: own research (the results do not add up to $100 \%$, because the respondents could choose several answers))

\begin{tabular}{||l|c|c||}
\hline \multirow{2}{*}{\multicolumn{1}{|c|}{ Possible answers }} & \multicolumn{2}{c|}{ Subjects } \\
\cline { 2 - 3 } & $\begin{array}{c}\text { Num- } \\
\text { ber }\end{array}$ & $\%$ \\
\hline $\begin{array}{l}\text { They contain nicotine, which is } \\
\text { a highly addictive substance }\end{array}$ & 33 & 55 \\
\hline $\begin{array}{l}\text { Tobacco smoke contains about } \\
\text { 4,000 chemical compounds, } 40 \\
\text { of which are carcinogenic }\end{array}$ & 28 & 47 \\
\hline All listed & 27 & 45 \\
\hline I do not know & 0 & 0 \\
\hline \hline
\end{tabular}

Figure 2 below shows graphically the level of knowledge of the respondents about the harmfulness of smoking.

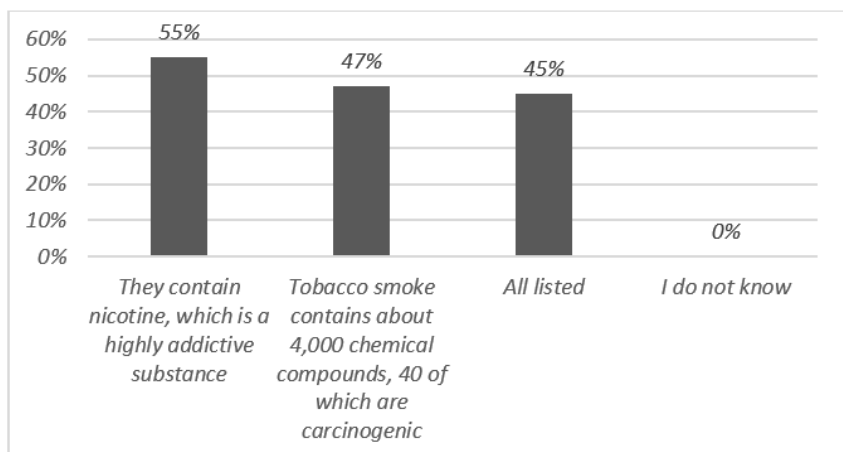

Figure 2 - The level of the respondents' knowledge about the harmfulness of smoking (source: own research)

Lung cancer risk factors are presented in Table 5 below.

The respondents' level of knowledge about the harmfulness of smoking is as follows: when asked whether a cigarette contains nicotine, which is a highly addictive substance, 33 people, which constituted $55 \%$ of the respondents, answered positively.

To the second question: does tobacco smoke contain about 4,000 chemical compounds, 40 of which are carcinogenic. 28 people gave a positive answer, which was $47 \%$ of the respondents.

However, the last question is: does nicotine smoke contain all the substances mentioned above? 27 people, which constituted as much as $54 \%$ of respondents, answered that they did not know.

Table 5. Lung cancer risk factors (source: own research (the results do not add up to $100 \%$, because the respondents could choose several answers))

\begin{tabular}{||l|c|c||}
\hline \multirow{2}{*}{\multicolumn{1}{|c|}{ Possible answers }} & \multicolumn{2}{c||}{ Subjects } \\
\cline { 2 - 3 } & $\begin{array}{c}\text { Num- } \\
\text { ber }\end{array}$ & $\%$ \\
\hline Smoking tobacco & 41 & 68 \\
\hline $\begin{array}{l}\text { Passive smoking - inhaling to- } \\
\text { bacco smoke }\end{array}$ & 39 & 65 \\
\hline A family history of lung cancer & 17 & 28 \\
\hline All listed & 19 & 32 \\
\hline I do not know & 0 & 0 \\
\hline
\end{tabular}

Figure 3 below graphically depicts the risk factors for lung cancer.

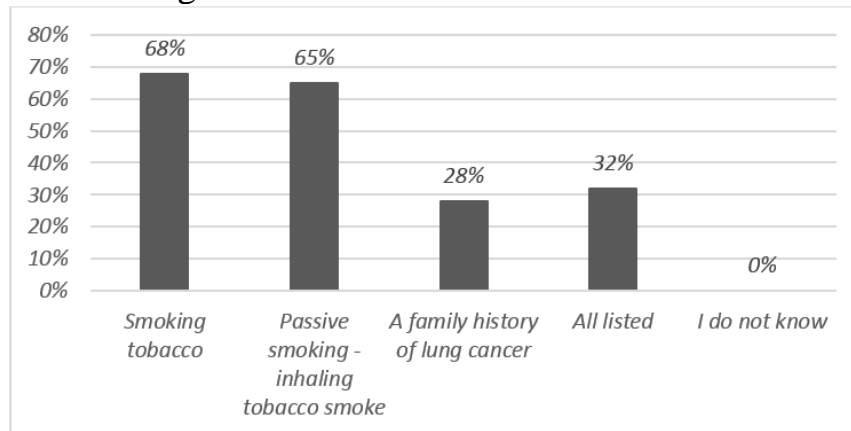

Figure 3 - Lung cancer risk factors (source: own research) 
Table 6 below presents lung cancer prevention methods.

The respondents were also asked about lung cancer risk factors. The answers were obtained: 41 people, $68 \%$ of the respondents claim that smoking is a risk factor for lung cancer. 39 respondents, which constitute $65 \%$, believe that passive smoking, i.e. inhaling tobacco smoke, may be the factor causing lung cancer. Also, a family history of cancer may be a precursor to lung cancer. 17 people think so, which constitutes $28 \%$ of respondents. 19 people, which constituted $32 \%$ of the respondents, believe that all the above-mentioned factors can cause lung cancer.

Table 6. Lung cancer prevention methods (source: own research (the results do not add up to $100 \%$, because the respondents could choose several answers))

\begin{tabular}{|l|c|c||}
\hline \multirow{2}{*}{ Possible answers } & \multicolumn{2}{|c|}{ Subjects } \\
\cline { 2 - 3 } & $\begin{array}{c}\text { Num- } \\
\text { ber }\end{array}$ & $\%$ \\
\hline $\begin{array}{l}\text { Quit smoking, tobacco products } \\
\text { and e - cigarettes }\end{array}$ & 51 & 85 \\
\hline Increasing physical activity & 8 & 13 \\
\hline $\begin{array}{l}\text { Performing preventive examina- } \\
\text { tions }\end{array}$ & 17 & 28 \\
\hline Eating anti-cancer vegetables & 6 & 10 \\
\hline Eating fruit regularly & 7 & 12 \\
\hline $\begin{array}{l}\text { Knowing the potential symp- } \\
\text { toms of lung cancer }\end{array}$ & 6 & 10 \\
\hline I do not know & 3 & 5 \\
\hline
\end{tabular}

Figure 4 below shows methods of lung cancer prevention

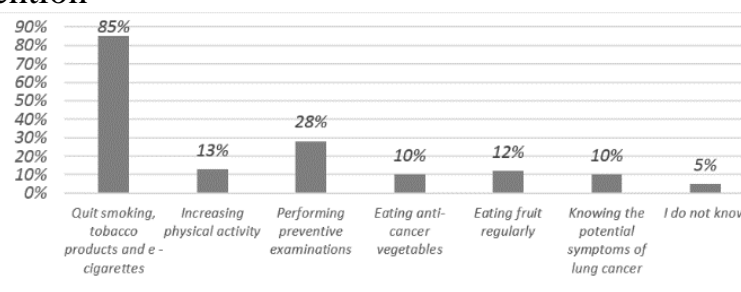

Figure 4 - Lung cancer prevention methods (source: own research)

The respondents were also asked if they knew methods of lung cancer prophylaxis. The following replies were given. 51 people, which constituted $85 \%$ of the respondents, answered that quitting smoking and tobacco products is an effective method of lung cancer prevention. Prevention can also be achieved by increasing physical activity. The affirmative answer was given by 8 people, which constituted $13 \%$ of the respondents. 17 people, who constitute $28 \%$ of respondents, claim that in the prevention of lung cancer it is important to undergo preventive examinations against the risk of cancer. There are 6 people who see preventive measures in a vegetarian diet, which is $10 \%$ of the respondents. 7 research participants, i.e. $12 \%$ of people, say that it is justified to eat fruit regularly. 6 people, i.e. $10 \%$, know that prophylaxis also means knowing the potential symptoms of lung cancer, because prompt therapy increases the chances of complications. There are also people who do not know lung cancer prophylaxis. There are 3 of them, which is as much as $5 \%$ of the total surveyed.

Table 7 below lists the most common symptoms of lung cancer.

Table 7. The most common symptoms of lung cancer (source: own research (the results do not add up to $100 \%$, because the respondents could choose several answers))

\begin{tabular}{|c|c|c|}
\hline \multirow{2}{*}{ Possible answers } & \multicolumn{2}{|c|}{ Subjects } \\
\cline { 2 - 3 } & $\begin{array}{c}\text { Num- } \\
\text { ber }\end{array}$ & $\%$ \\
\hline cough & 30 & 50 \\
\hline Wheezing & 6 & 10 \\
\hline Hemoptysis, & 47 & 78 \\
\hline dyspnoea & 23 & 38 \\
\hline hoarseness & 5 & 8 \\
\hline Pain in the chest and shoulders & 4 & 6 \\
\hline Feeling tired and losing weight & 4 & 6 \\
\hline I do not know & 4 & 6 \\
\hline
\end{tabular}

The respondents' knowledge of the most common symptoms of lung cancer was tested and the results presented below were obtained. 30 people, or $50 \%$ of the population, say that salsify is a symptom of cancer. Others say that wheezing is a symptom of lung cancer and there were 6 of these people, which constituted $10 \%$ of respondents.

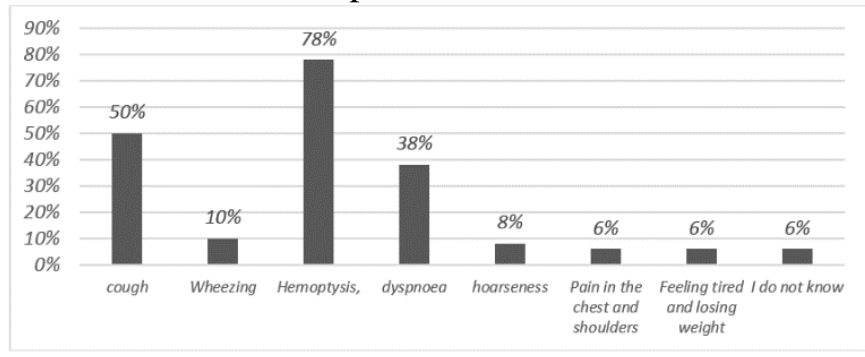

Figure 5 -The most common symptoms of lung cancer (source: own research)

Hemoptysis as a symptom of cancer was indicated by 47 people, which constitutes $78 \%$ of the respondents. Dyspnea was also noted as a possible symptom of cancer. This answer was given by 23 people, i.e. $38 \%$. According to 5 respondents, hoarseness may be a symptom of cancer in $8 \%$. Fatigue and weight loss were also mentioned as symptoms. 4 people, which constituted $6 \%$ of the respondents, leaned 
towards such a statement. However, what is worrying, as many as 4 people could not identify any of the most common symptoms related to the possibility of lung cancer.

Conclusions. The aetiology of some cancers is not clear. They are the result of many genetic mutations which may be influenced by various physical and chemical factors, viral infections, type of diet, stimulants. Cancer development is a slow process (several years) or aggressively fast (one month).

The main aim of the study was to find out about the level of knowledge of adolescents about lung cancer. The collected material allowed for the verification of the hypotheses that were put forward during the preparation of the methodological work. Based on the research, the following conclusions were drawn:

1. Adolescents demonstrated a good knowledge of the impact of negative pro-health behaviours on the possibility of developing lung cancer

2. Adolescents think that they influence whether they get lung cancer

3. Adolescents know health-promoting behaviours that reduce the risk of falling ill

4. Adolescents do not have a basic understanding of the symptoms of lung cancer.

In conclusion, it can be assumed that the respondents have a basic knowledge of lung cancer. The state of knowledge seems to be sufficient to apply effective anti-tumour lung prophylaxis.

Summary. To improve the situation of lung cancer in society, numerous social organizations and associations take part in social campaigns dedicated to all citizens, regardless of age and sex. Some postulates, the introduction of which could increase the health security of the state and eliminate some environmental threats, such as passive smoking, will be presented below. These postulates have the overarching goal of changing the model of lung cancer prevention and care in Poland. The changes should be comprehensive - from prevention (primary and secondary), through diagnostics and treatment, posttreatment care (including rehabilitation and psychooncological care), to observation aimed at detecting and treating complications of the disease and anticancer therapy as well as early detection of possible recurrence of the disease.

By introducing primary prevention, the incidence of lung cancer could be reduced. This can be achieved through the ongoing anti-cancer public education about the adverse health effects of smoking. Particular emphasis should be placed on the education of children, school children and parents - activities aimed at stopping the trend of the increasing popularity of e-cigarettes among young people. The elimination of all possible forms of advertising for tobacco products, a significant increase in the price of cigarettes and the development of the Smoker Aid Clinics network as well as including lung cancer prevention among primary care physicians and occupational medicine physicians also seem to be key in reducing the number of lung cancer cases.

On the other hand, the purpose of implementing secondary prevention would be to increase the number of patients diagnosed at earlier stages of lung cancer, for example by implementing and popularizing early detection programs - screening tests using low-dose computed tomography, conducted in risk groups. Introducing uniform standards for assessing test results as part of the lung cancer early detection program, comprehensive diagnostics, treatment and adopting an individual therapy model for the oncological treatment process. The standardization of patient care, the availability of innovative solutions, the creation of a uniform medical register of lung cancer patients, which would constitute the basis for the reliable planning and monitoring of the treatment process, shortening the waiting time for the availability of innovative therapies for patients, seem to be key in the prevention of lung cancer.

It would also be worthwhile to analyse the results of studies obtained by interviewing girls and boys, as well as young people from rural and urban areas, which will allow them to be taken into account when formulating cancer prevention measures. Given that smoking is becoming a bad habit of the younger age group than the study, it would be worthwhile to expand the age range and conduct such research among children, for example, from the age of 7 years. At this age, children are more receptive to and aware of health hazards

\section{References}

1. Tuchowska P., Worach-Kardas H., Marcinkowsk J.T. (2013), 'The most common malignant neoplasms in Poland - the main risk factors and possibilities to optimize preventive measures". Problems of Hygiene and Epidemiology, 94(2), pp. 166-171.

2. Didkowska J. (2011)," The epidemiology of malignant neoplasms in Poland", J. Meder (ed.). "Fundamentals of clinical oncology", CMKP Warsawa, pp. 5-17.

3. Wojciechowska U, Olasek P, Czauderna K, Didkowska J. (2016), Malignant neoplasms in Poland in 2014. Oncology Center - Institute, Warsaw: httl://onkologia.org.pl/publikacje4.

4. Nowakowski Z. (2008), National security the evolution of the concept and scope, [in:] National security and crisis management in Poland in the $21 \mathrm{st}$ century - dilemmas and challenges, ed. T. Jemioła, K. Rajchel, Warsaw, pp. 87.

5. Zięba R. (1997), National security, [in:] National and international security, Warsaw, pp. 11. 
6. Rabiega A. (2009), Protection of human life and health in the activities of administrative entities in the field of healthcare, Warsaw, pp. 5, 11.

7. Paplicki M. (2016), Health security of citizens in the state internal security system, "Acta Universitatis Wratislaviensis" No. 3738 (in), Przegląd Prawa i Administracji, Wrocław, CVI, p. 257.

8. The National Lung Screening Trial Research Team. Reduced lung-cancer mortality with low-dose computed tomographic screening. N Engl J Med. 2011; 365(5): 395-409, doi: 10.1056/ NEJMoa1102873, indexed in Pubmed: 21714641.

\section{Список літератури}

1. Tuchowska P. Najczęstsze nowotwory złośliwe w Polsce - główne czynniki ryzyka i możliwości optymalizacji działań profilaktycznych" / P.Tuchowska, H. Worach-Kardas, J.T. Marcinkowsk. Problemy Higieny i Epidemiologii. 2013. 94(2). S. 166-171.

2. Didkowska J. Epidemiologia nowotworów złośliwych w Polsce, J. Meder (red.). „Podstawy onkologii klinicznej". - CMKP. Warszawa. 2011. S. 5-17.
3. Wojciechowska U. Nowotwory złośliwe w Polsce w 2014 roku. / U. Wojciechowska, P. Olasek, K. Czauderna, J. Didkowska // Centrum Onkologii Instytut, - Warszawa, 2016: httl://onkologia.org. pl/publikacje4.

4. Nowakowski Z. Bezpieczeństwo narodowe - ewolucja pojęcia i zakresu, [w:] Bezpieczeństwo narodowe i zarządzanie kryzysowe Polsce w XXI wieku - dylematy i wyzwania, red. T. Jemioła, K. Rajchel, Warszawa, 2008, s. 87.

5. Zięba R. Bezpieczeństwo narodowe, [w:] Bezpieczeństwo narodowe i międzynarodowe, Warszawa, 1997, s. 11.

6. Rabiega A. Ochrona życia i zdrowia ludzkiego w działaniach podmiotów administrujących w sferze opieki zdrowotnej, Warszawa, 2009, s. 5, 11.

7. Paplicki M. Bezpieczeństwo zdrowotne obywateli w państwowym systemie bezpieczeństwa wewnętrznego, „Acta Universitatis Wratislaviensis" nr 3738 (w), Przegląd Prawa i Administracji, Wrocław, 2016, s. 257.

8. The National Lung Screening Trial Research Team. Reduced lung-can-cer mortality with low-dose computed tomographic screening. N Engl J Med. 2011; 365(5): 395-409, doi: 10.1056/NEJMoa1102873, indexed in Pubmed: 21714641.

\footnotetext{
* Науково-методична стаття
} 